\title{
The Candida albicans Inhibitory Activity of the Extract from Papaya (Carica papaya L.) Seed Relates to Mitochondria Dysfunction
}

\author{
Tao Zhang ${ }^{1,2}$ and Weijun Chen ${ }^{1, *}$ \\ 1 College of Food Science, Hainan University, Haikou 570228, China; tao_zhang0922@hotmail.com \\ 2 State Key Laboratory of Food Science and Technology, School of Food Science and Technology, \\ Jiangnan University, Wuxi 214122, China \\ * Correspondence: chenwj@hainu.edu.cn; Tel.: +86-136-1756-6001
}

Received: 26 July 2017; Accepted: 18 August 2017; Published: 25 August 2017

\begin{abstract}
The inhibitory activity of the papaya seed extract (PSE) on Candida albicans (C. albicans) was determined by turbidimetry method. The inhibitory mechanisms were also evaluated from the prospective of reactive oxygen species (ROS) generation, mitochondrial membrane potential (MMP) decrease, and the activities of four complex enzymes in mitochondria respiratory chain. Results obtained from this study indicated that the PSE exhibited an effective inhibitory activity on C. albicans and induced significant accumulation of ROS and collapse of MMP. The Complex I and Complex III exhibited continues significant decrease in mitochondrial enzyme activity assays, but the Complex II and Complex IV activities were not positively correlated. Furthermore, the GC-MS analysis demonstrated that the PSE represents a rich and high-purity source of benzyl isothiocyanate (BITC), which indicated the BITC may be responsible for the mitochondrial dysfunction.
\end{abstract}

Keywords: papaya seed; C. albicans; benzyl isothiocyanate; mitochondria dysfunction; reactive oxygen species

\section{Introduction}

Papaya (Carica papaya L.) is an important economic fruit in both tropical and sub-tropical region [1]. Papaya fruits have amounts of carbohydrates and water, low in calories but rich in minerals and natural vitamins, particularly vitamin A and vitamin C [2]. The central cavity of the flesh contains large quantities of seeds that comprise about $15 \%$ of the wet weight of the papaya fruit [3]. The papaya seeds had a high content of lipid $(29.16 \%)$ and protein $(25.63 \%)$. The lipid in the papaya seeds is considered economically attractive for industrial extraction, especially when compared to conventional oilseed crops such as corn and soybean [4]. Traditionally, papaya seeds were used in parts of Asia and South America as a vermifugal [5] and seed preparations were also used in folk medicine due to its abortive properties to favor a good menstrual flow [6]. In recent years, many studies have been conducted to utilize the papaya seeds, and extensive research has been carried out on the use of the seeds as a source of oil [7-9], It was reported that the papaya seed oil had an interesting composition ( $72 \%$ of monounsaturated fatty acids with $71 \%$ oleic acid) and hence representing a promising source of oleic oil for various applications [10]. Furthermore, the papaya seed extract (PSE) has been pronounced with some special functions such as antibacterial [11], anti-fertility [12-15], antihelminthic and antiamoebic [16] activities. Previous studies have discovered many bioactive compounds existed in papaya seeds [17], including substantial amounts of carotenoid pigments, isothiocyanate and phenolic compounds [8]. However, the seeds of papaya were generally discarded and little attention was given for further application of these bioactive compounds. 
Candida albicans (C. albicans), a common fungus, is frequently a benign member of the skin and mucosal flora. Research has shown that $C$. albicans could induce mucosal membranes diseases [18]. Antecedent colonization of mucosal surfaces with C. albicans could cause life-threatening infections in abnormal hosts. Approximately $75 \%$ of women will have one episode of candida vaginitis in their lifetime, with half having at least one recurrence [19], and invasive candidiasis is particularly common in intensive care units where mortality rates reach $45-49 \%$ [20]. Even worse, the resistance of pathogenic fungi, in particular C. albicans and non-C. albicans species isolated from patients, against antifungal agents has increased [21]. Based on the increasing side-effects of polyenes and azoles, novel antifungal therapies with fewer side effects on humans are urgently required for effective management of candidiasis [22].

Mitochondria dysfunction involves in many antifungal activities. In the endosymbiotic association of oxidative bacteria and most eukaryotic cells, mitochondria have become an increasingly important target for cellular research. Recently, the extract of papaya seeds was reported to exhibit an antifungal activity against Candida albicans $[23,24]$. However, possible mechanism of the inhibitory activity was ignored. The aim of this study was to highlight the potential compounds in the PSE as a new natural source for C. albicans inhibition. The inhibitory mechanisms were also evaluated from the prospective of reactive oxygen species (ROS) generation, mitochondrial membrane potential (MMP) decrease, and the activities of four complex enzymes in mitochondria.

\section{Results}

\subsection{C. albicans Inhibitory}

C. albicans inhibitory result displayed that the PSE have an effective inhibitory activity (Figure 1). The inhibition activity were increased with the increasing concentration $(p<0.01)$ : when the concentration was $18 \mu \mathrm{g} / \mathrm{mL}$, the inhibition was $95.08 \pm 0.62 \%$ and found not significantly different $(p>0.05)$ with $16 \mu \mathrm{g} / \mathrm{mL}$. According to the Clinical and Laboratory Standards Institute (CLSI) interpretative guidelines on antifungal susceptibility testing, the half maximal inhibitory concentration $\left(\mathrm{IC}_{50}\right)$ between 16 and $32 \mu \mathrm{g} / \mathrm{mL}$ is considered as susceptible dose dependent [25]. In this study, the $\mathrm{IC}_{50}$ of PSE was calculated as $9.36 \mu \mathrm{g} / \mathrm{mL}$. It was suggested that the PSE exhibited a remarkable inhibitory activity on C. albicans.

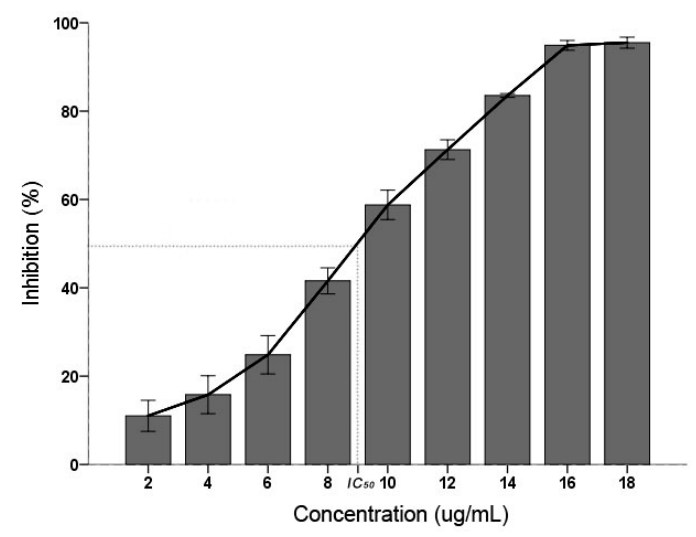

Figure 1. Effects of the inhibitory activity on the inhibition of C. albicans. Inhibition activity was determined after $24 \mathrm{~h}$ of treatment with concentrations of $2-18 \mu \mathrm{g} / \mathrm{mL}$. Data $(n=3)$ are expressed as mean \pm SD. The statistical significant of differences was calculated using one-way ANOVA with Bonferroni's post hoc test.

\subsection{ROS Increase}

ROS production and accumulation is a common denominator in many diseases. Environmental insults can lead to severe cellular damage leading to physiological dysfunction and cell 
death in virtually all aerobes. The fluorescent probe DCFH-DA has been widely used for measurement of ROS formation in cells [26,27]. As shown in Figure 2, the PSE caused a continuous increase in ROS level of $C$. albicans cells. With the treatment time prolonged, there was significant $(p<0.05)$ increase in ROS accumulation. The ROS increased to the maximum level $(29.51 \pm 0.84 \%)$ when treated for $100 \mathrm{~min}$, which was corresponded to 1.30 times compared with the control treated for $0 \mathrm{~min}$. Previous studies have shown that $C$. albicans treated with $8 \mu \mathrm{g} / \mathrm{mL}$ plagiochin $\mathrm{E}$, ROS would increased 1.28 times after two hours [26]. Though concentration in this study changed, the result still reflected that the PSE exhibited a strong vitality for ROS accumulation in C. albicans. By taking the ROS generation in previous study as a reference [26], the ROS increase in levels (Figure 2) were not low, especially when treated for $20 \mathrm{~min}$.

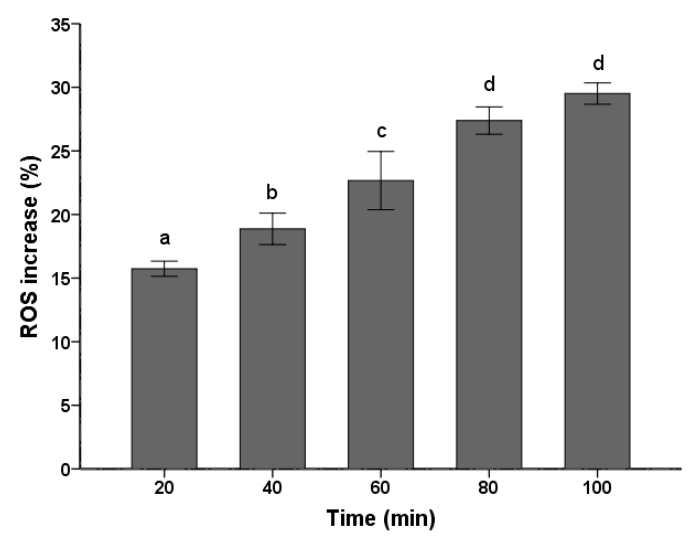

Figure 2. Effects of the PSE on the increase of ROS in C. albicans cells. Cells were treated with $20 \mu \mathrm{g} / \mathrm{mL}$ extract for 20 to $100 \mathrm{~min}$, stained with DCFH-DA $(10 \mu \mathrm{M} / \mathrm{L})$ for $15 \mathrm{~min}$ and analyzed by fluorescence. Fluorescence intensity is an indication of ROS levels in C. albicans cells. Data $(n=3)$ are expressed as mean \pm SD. The statistical significant of differences was calculated using one-way ANOVA with Bonferroni's post hoc test. Different letters represent significant difference $(p<0.05)$.

\subsection{MMP Decrease}

Decrease of MMP has been considered a characteristic feature in the early stage during apoptosis. As shown in Figure 3, C. albicans cells treated with the PSE exhibited significant $(p<0.01)$ decrease in MMP at $5-25 \mu \mathrm{g} / \mathrm{mL}$. The decrease in MMP rates was increased with the increasing of the concentration. The $25 \mu \mathrm{g} / \mathrm{mL}$ treatment group rapidly increased the proportion of Rhodamine 123 negative cell to $79.27 \pm 1.10 \%(p<0.01)$. The data indicated that $C$. albicans cell exposure to the extract resulted in MMP collapse. MMP depolarization promotes ROS production. The results obtained were consistent with previous results of similar studies about medioresinol leading to MMP decrease of $C$. albicans [26].

\subsection{The Activity of Mitochondrial Complex Enzymes}

The activities of mitochondrial complex enzymes are the most commonly assayed parameters of mitochondrial functions. Activities of the four complexes in the electron transfer chain in C. albicans were measured. As shown in Figure 4, the extract induced some decrease in Complex I, Complex II, Complex III and Complex IV activities to different degrees. However, with the increasing of the PSE concentration, only the activities of Complex I (Figure 4A) and Complex III (Figure 4C) exhibited continued significant decreasing $(p<0.05)$. No obvious and sustaining changes $(p>0.05)$ were found in Complex II (Figure 4B) or Complex IV (Figure 4D) when concentration was higher than $10 \mu \mathrm{g} / \mathrm{mL}$. With $25 \mu \mathrm{g} / \mathrm{mL}$ PSE treatment, the activities of four complex enzymes reached the lowest activities, $9.47 \%, 68.10 \%, 25.50 \%$ and $67.32 \%$, respectively $(p<0.01)$. 


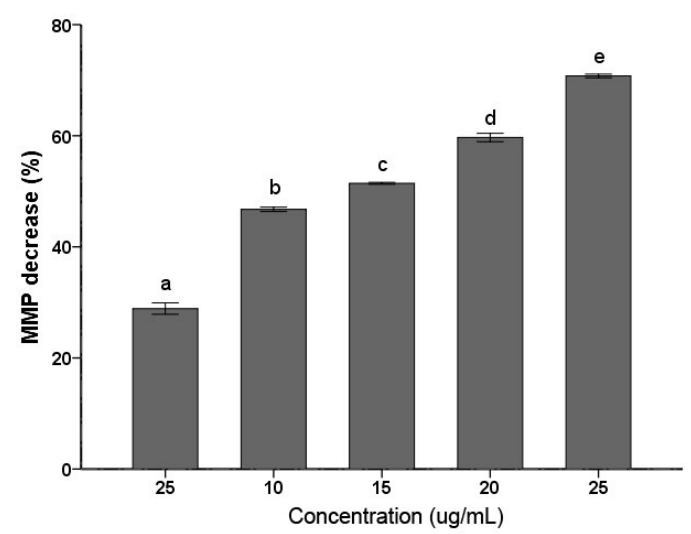

Figure 3. Effects of the PSE on the loss of mitochondrial membrane potential (MMP) in C. albicans cells. Cells were treated with or without the extract for $24 \mathrm{~h}$. After incubation, cells were stained with Rhodamine $123(20 \mu \mathrm{M} / \mathrm{L})$ for $30 \mathrm{~min}$ at $37^{\circ} \mathrm{C}$ and analyzed by fluorescence. The reduced fluorescence of Rhodamine 12 was determined as the reduced MMP. Data $(n=3)$ are expressed as mean \pm SD. The statistical significant of differences was calculated using one-way ANOVA with Bonferroni's post hoc test. Different letters represent significant difference $(p<0.05)$.
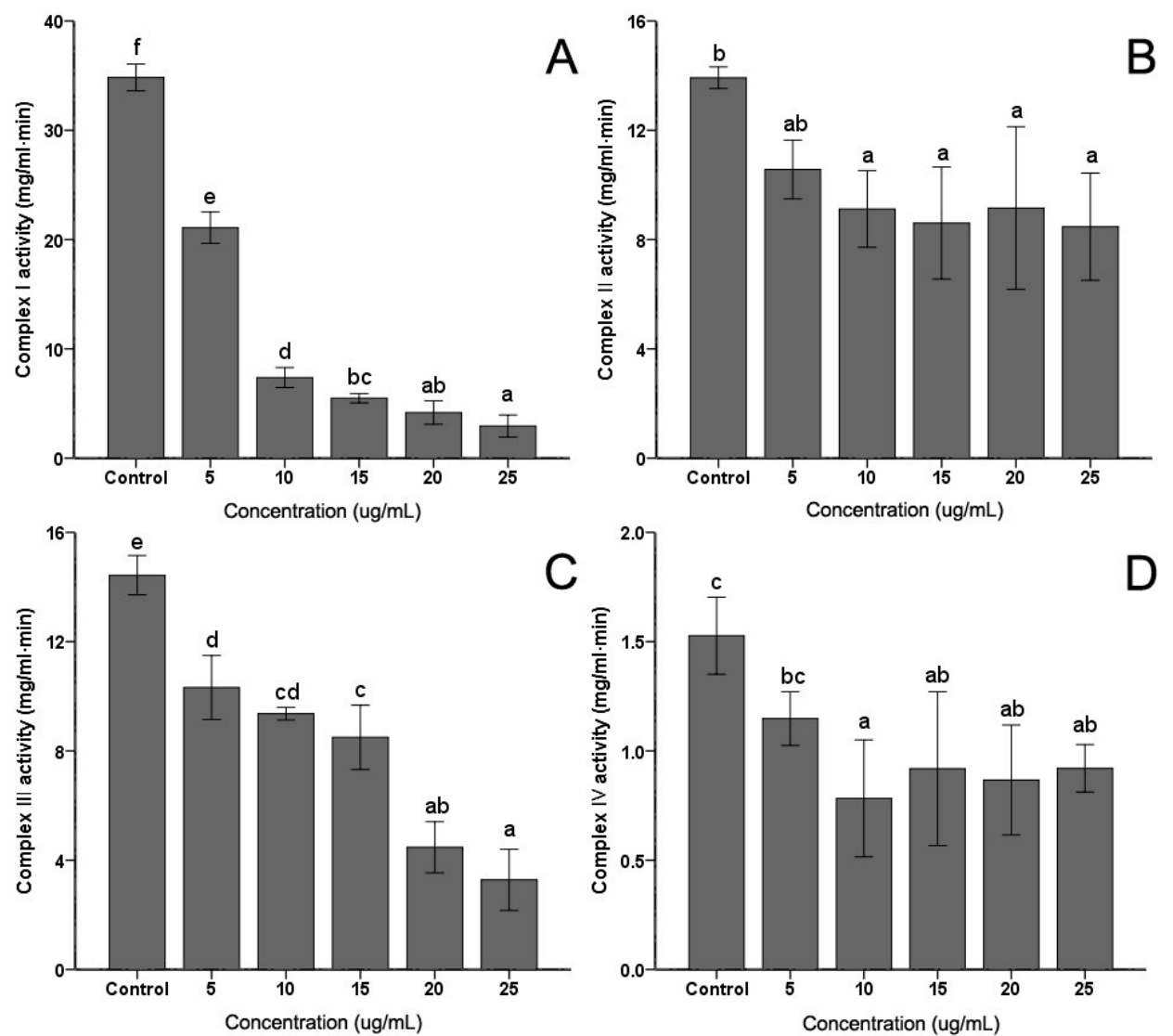

Figure 4. Effects of the PSE on the activities of mitochondrial complex enzymes in C. albicans cells. C. albicans cells were pretreated with different concentrations (0 to $25 \mu \mathrm{g} / \mathrm{mL}, 24 \mathrm{~h}$ ): (A) Complex I; (B) Complex II; (C) Complex III; and (D) Complex IV. Data $(n=3)$ are expressed as mean \pm SD. The statistical significant of differences was calculated using one-way ANOVA with Bonferroni's post hoc test. Different letters represent significant difference $(p<0.05)$. 


\subsection{Chemical Composition of the Extract}

GC-MS analysis result showed four compounds were identified as constituents of PSE, as presented in Figure 5. It was shown that PSE represented a rich and high-purity source of benzyl isothiocyanate (BITC, 98.28\%). Other compounds, such as benzeneacetaldehyde $(0.10 \%)$, benzyl nitrile $(1.41 \%)$ and benzaldeehyde $(0.21 \%)$, were also found. Previous studies on the composition of papaya seed extract demonstrated that BITC was the major bioactive compound [28]. The content of BITC could reach $99.36 \%$ [23]. Several methodologies have been reproted to obtain a high content of BITC [28-30]. BITC is a non-polar substance and mainly extracted by organic solvent in the mentioned previous sdudies. In contrast to solvent extract, steam distillation-extraction could get rid of the less volatile material and the purification process become easier. BITC are thought to be the bioactive compounds in PSE, responsible for the anthelmintic effect. However, the manner in which BITC is handled by the body is unclear. It seems that more studies need to be done to characterize the side effects of BITC before it can be firmly concluded that it is safe for further use.

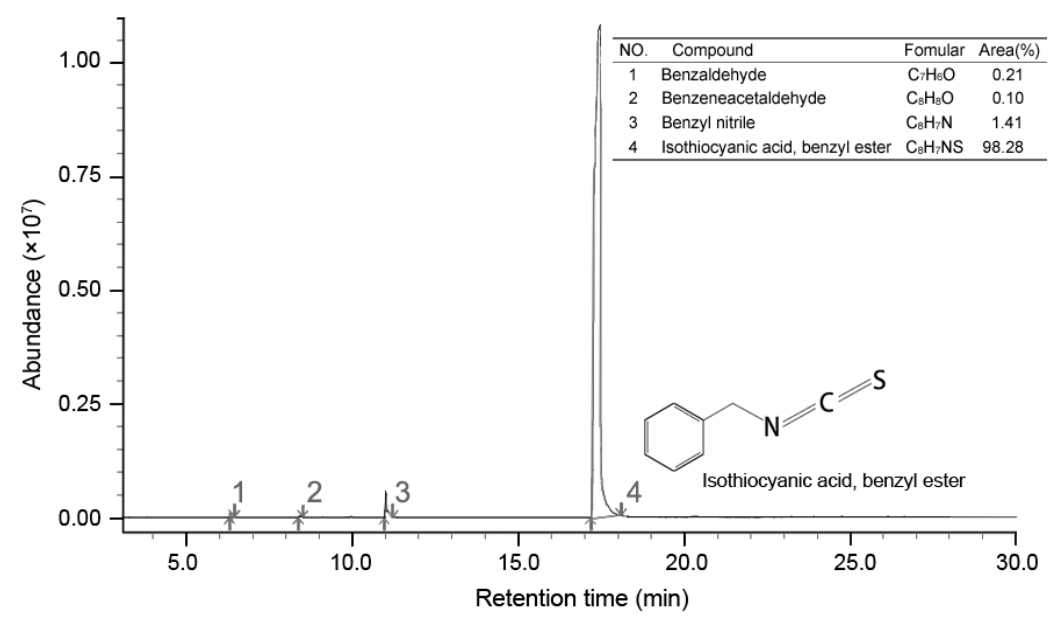

Figure 5. Total ion-current chromatogram of PSE by GC-MS.

\section{Discussion}

Many kinds of plants have been widely used for the treatment of various diseases for a very long time. Recently, interest in drugs of plant origin has significantly increased due to the less harmful side effects and wider availability. Research is being conducted all over the world to determine whether plants that are traditionally used in the treatment of various diseases are appropriate for intended use [31]. In this study, the data indicated that PSE could be utilized as an effective inhibitory medicine of C. albicans (Figure 1) owing to its high content of BITC (Figure 5). Previous studies have shown BITC is the major principle in papaya seeds [17]. This study obtained a high purity of BITC which was in good accordance with previous studies [29]. Furthermore, BITC is a volatile and relatively insoluble in water, the advantages of steam distillation extraction method is that BITC and volatile oil would be extracted while non-volatile oil and other impurities would be excluded. Thus, distillation of this compound from an aqueous solution with high purity in the current condition was not surprising. This study provided a preparation method of BITC for intensive research or industrial production. With azoles resistance C. albicans strains emerging in immune-compromised patients [32], the PSE may also serve as a novel drug and give a promising prospect for cardiac diseases treatment. However, intensive studies need to be done to investigate the side effects of BITC before firmly concluding that BITC is safe for further use.

Oxidative stress was considered e an important condition to promote cell death in response to a variety of signals and psychophysiological situations. ROS, which is predominantly produced in the mitochondria, if excessive, may lead to the free radical attack of membrane phospholipids and 
loss of mitochondrial membrane potential. Consequently, releases apoptosis-inducing factors that activate caspase cascades and cause nuclear condensation [33]. In this study, it was illustrated that the extract induced rapid and significant ROS generation in C. albicans cells (Figure 2). The results corroborate the similar conclusion obtained before [26], which reported that plagiochin E induced ROS accumulation in C. albicans. In addition, this study confirmed that ROS formation was the major event in BITC induced killing of C. albicans. Meanwhile, researches demonstrated that the antifungal action of many antifungal agents such as miconazole [34], indole-3-carbinol [35], and plagiochin E [26] are involved in the induction of ROS formation in C. albicans. Thus, the results were supporting the hypothesis that the rapid generation of ROS plays an important role in C. albicans cell death. Moreover, ROS generation is also correlated with the decrease of MMP. A rapid collapse of MMP was always found in some anticancer compounds induced apoptosis in cells [36]. The data in this study clearly show that the treatment with the PSE could lead to a loss of MMP (Figure 3). In many systems, cell death was associated with the loss of MMP, which was regarded as a limiting factor in that process. Reduction of the MMP is among the changes encountered during early reversible stages of deaths and is preceded by cytochrome c release in several cell types [37]. The result was in accordance with previous studies which suggested that a breakdown of MMP related to C. albicans cell deaths [26,35].

To investigate the mechanism of ROS accumulation and MMP decrease induced by PSE in C. albicans cells, the activities of four mitochondria complex enzymes in C. albicans cells (Figure 4) were evaluated. It was found that the Complex I and Complex III activities were significantly decreased, but Complex II and Complex IV activities were not positively correlated with the concentration. The changing of the enzyme activities indicated that PSE induced C. albicans death relates to the Complex I and Complex III dysfunctions. Mitochondria are an essential part of normal cellular function, particularly in the process of oxidizing carbon substrates to generate intracellular energy exchange. Changes of the mitochondrial protein activity were crucial in a number of cellular processes including the permeability transition and cell death. The influence of substances on mitochondria respiratory complex caused by drugs has already been reported [38]. The results were in accordance with previous findings: a reduction in the activities of Complex I and Complex III induced by ROS production could lead to an oxidation of these proteins [39]. On the other hand, an increase in activity of these enzymes may also correspond to an increase in oxidative stress. Furthermore, studies showed that BITC targeted mitochondria respiratory chain to trigger ROS-dependent apoptosis [40]. Generation of ROS by BITC led to induction of apoptosis in cancer cells [41,42]. These finds also proved the role of BITC in ROS production and mitochondrial dysfunction in cells.

Previous studies suggested that membrane lipid peroxidation and subsequent membrane dysfunction observed in cyanide intoxication is related in part to a compromised antioxidant defense. Given that cyanic acid group compounds are well known for their activities against mitochondrial electron transport chain Complex II and Complex IV, cyanide could increase the generation of ROS in mitochondria. Furthermore, it has been considered that enzyme activity of the mitochondria protein was inhibited by potassium cyanide. PSE may interfere with anti-ROS enzyme. Thus, the C. albicans inhibitory mechanism of the PSE can be illustrated as in Figure 6. First, BITC, the major compound in the PSE, exerted its antifungal activity through ROS accumulation and MMP depolarization in C. albicans. Then, the activation of mitochondrial apoptosis pathway, including Complex I and Complex III dysfunctions, was initiated. However, the detailed relationship among Complex I, Complex III and ROS accumulation or MMP decreasing is still under study. Further investigation is needed to elaborate why Complex II and Complex IV were not distinctly affected. In general, the results indicated the PSE could serve as a novel drug for cardiac diseases. 


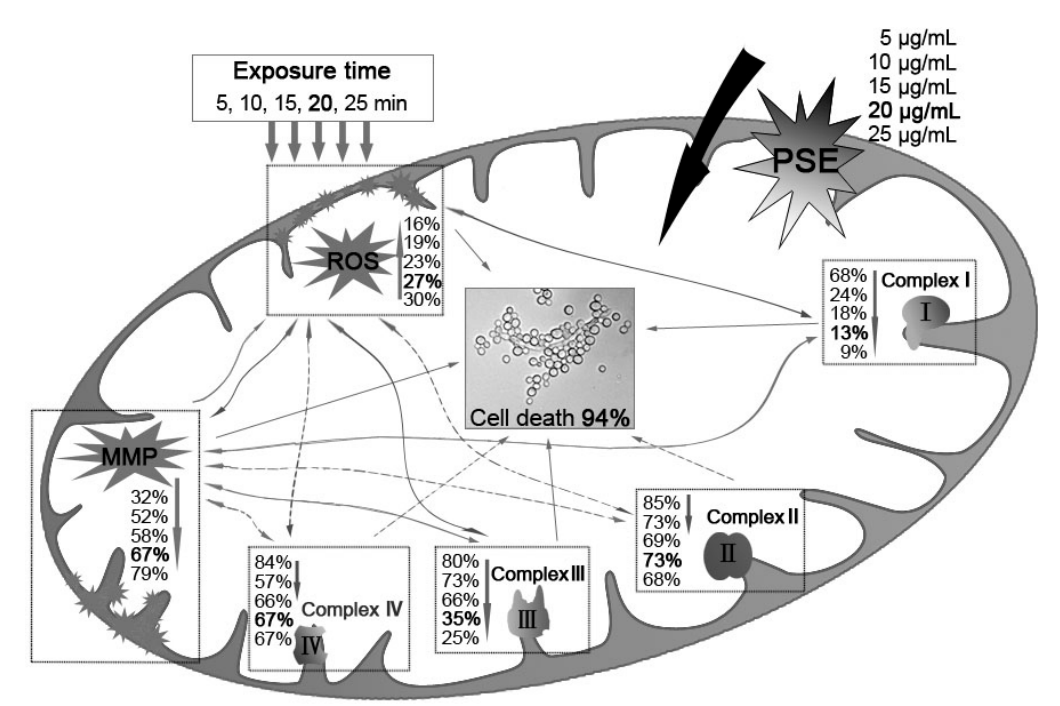

Figure 6. The C. albicans inhibitory mechanism of BITC. BITC inhibition correlated exponentially with MMP decay, ROS accumulation and the decreasing activities of mitochondria complex enzymes. Bold value was defined as the data when a significant cell death (94\%) was induced. Real lines with arrows represent a significant and direct correlation, and dotted lines mean an uncertain relationship that requires further study. The percentages beside express the decrease or increase rates caused by treatment of different concentrations of PSE compared to the control.

\section{Materials and Methods}

\subsection{Plant Material and Extraction}

The papaya seeds were purchased from local market and identified at Tropical Oil Crops Research Institute, Ministry of Agriculture, Wenchang China. After crushed, $100 \mathrm{~g}$ papaya seeds were placed in a round bottomed flask then steam distillation at $100{ }^{\circ} \mathrm{C}$ allowed for two hours. After centrifugation for $10 \mathrm{~min}$ at $5000 \times \mathrm{g}$, anhydrous sodium sulfate was added to remove water and then stored at $4{ }^{\circ} \mathrm{C}$ in the dark. The extract yield was found to be $0.14 \pm 0.02 \%(w / w)$ as calculated on dry weight with a density of $1.12 \mathrm{~g} / \mathrm{mL}$.

\subsection{Chemical and Reagents}

Sodium succinate, rotenone, cytochrome $c$, coenzyme $Q_{1}$, coenzyme $Q_{10}$, antimycin $A$, decylubiquinol, $2^{\prime}, 7^{\prime}$-dichlorofluorescin diacetate (DCFH-DA) and Rhodamine 123 were purchased from Sigma (St. Louis, MO, USA). Tris base and NADH were purchased from Amersco Inc. (Palm Harbor, FL, USA). 2,6-Dichlorophenolindophenol (DCPIP) was purchased from Merck \& Co. Inc. (Kenilworth, NJ, USA). Bovine serum albumin (BSA) for protein quantification was purchased from Sinopharm Chemical Reagent Co., Ltd. (Shanghai, China). All the other reagents used were of reagent grade and prepared in double-distilled water.

\subsection{Microorganism and Culture Condition}

The strain C. albicans was obtained from the American Type Culture Collection (ATCC). Cultures were maintained on a Sabouraud's glucose medium (10 g/L of peptone, $20 \mathrm{~g} / \mathrm{L}$ of agar, $40 \mathrm{~g} / \mathrm{L}$ of glucose). The culture temperature was maintained at $32{ }^{\circ} \mathrm{C}$ and conducted at free $\mathrm{pH}$ with $300 \mathrm{rpm}$.

\subsection{C. albicans Inhibitory Activity}

C. albicans inhibitory activity was determined by a turbidimetry assay [43]. The extract solution (3.6 mg PSE dissolved in $1 \mathrm{~mL}$ ethanol and diluted with water to $100 \mathrm{~mL}$ ) was mixed with a 12-hour-old 
culture of $C$. albicans $\left(\mathrm{CFU}=10^{6}\right.$ ) on yeast extract peptone dextrose (YPD) broth (20 g/L of peptone, $10 \mathrm{~g} / \mathrm{L}$ of yeast extract, $20 \mathrm{~g} / \mathrm{L}$ of glucose) and the final PSE concentration varying from 2 to $18 \mu \mathrm{g} / \mathrm{mL}$ were added to 96 -wells plate. After the microplates were incubated at $30^{\circ} \mathrm{C}$ for $24 \mathrm{~h}$, the absorbance at $600 \mathrm{~nm}$ was measured. The inhibitory activity was calculated with the following equation:

$$
\text { Inhibition }(\%)=\left(A_{1}-A\right) /\left(A_{1}-A_{0}\right) \times 100
$$

where $A$ is the absorbance of the sample with the treatment of PSE; $A_{1}$ is the absorbance without PSE treatment; and $A_{0}$ is the absorbance of the culture medium.

\subsection{Isolation of Mitochondria}

Isolation of mitochondria were performed according to the method of Niimi with slight modifications [44]. Cells grown in YPD broth at $30{ }^{\circ} \mathrm{C}$ to early stationary phase were cultured, diluted to $5 \times 10^{6} \mathrm{CFU} / \mathrm{mL}$ with fresh YPD broth at $30^{\circ} \mathrm{C}$ for $24 \mathrm{~h}$, after centrifugation at $5000 \times g$ for $10 \mathrm{~min}$, the pellet was resuspened in homogenization medium (50 mM Tris-HCl, $2 \mathrm{mM}$ EDTA, $\mathrm{pH} 7.5$ ) and homogenized. Then was supplemented with $2 \%$ glucose before freezing and thawing three times repeatedly and centrifuged at $2000 \times \mathrm{g}$ for $10 \mathrm{~min}$ to remove the cell debris and unbroken cells. The supernatants were collected and centrifuged at $12,000 \times g$ for $45 \mathrm{~min}$. Then the pellet was resuspened in buffer ( $50 \mathrm{mM}$ Tris-HCl, $2 \mathrm{mM}$ EDTA, $\mathrm{pH}$ 5.0) incubated for $5 \mathrm{~min}$, and centrifuged at $5000 \times \mathrm{g}$ for $30 \mathrm{~s}$. The pellet was collected as mitochondria resuspened in $50 \mathrm{mM}$ Tris- $\mathrm{HCl}$ $(\mathrm{pH} 7.5)-2 \mathrm{mM}$ EDTA-20\% $(v / v)$ glycerol then stored at $-30{ }^{\circ} \mathrm{C}$. Finally, the protein level was determined by Coomassie Brilliant Blue method.

\subsection{Measurement of Reactive Oxygen Species (ROS) Formation}

Generation of ROS was measured by the oxidative-sensitive fluorescent probe DCFH-DA [45]. Intracellular ROS can oxidize DCFH-DA to the highly fluorescent compound dichlorofluorescein. At 20, 40, 60, 80 and $100 \mathrm{~min}$ following the treatment with $20 \mu \mathrm{g} / \mathrm{mL}$ PSE, the medium was aspirated and replaced by DCFH-DA $(10 \mu \mathrm{M})$ for a further $30 \mathrm{~min}$ at $37^{\circ} \mathrm{C}$. The cells were collected and then analyzed by fluorescence microplate reader.

\subsection{Measurement of Mitochondrial Membrane Potential (MMP)}

Depolarization of MMP during cell apoptosis results in the loss of Rhodamine 123 from the mitochondria and a decrease in intracellular fluorescence intensity. The effects of the PSE on the MMP was measured by fluorescence microscopy using Rhodamine 123 according to the procedure as described previously [36]. Briefly, at $24 \mathrm{~h}$ after the treatment with $0-25 \mu \mathrm{g} / \mathrm{mL}$ PSE, the cells were harvested and washed twice with Tris- $\mathrm{HCl}(50 \mathrm{mM}, \mathrm{pH} 7.5)$, incubated with $10 \mu \mathrm{M}$ Rhodamine 123 for $30 \mathrm{~min}$ at $30^{\circ} \mathrm{C}$ in the dark and gently washed three times with Tris- $\mathrm{HCl}$. The intracellular fluorescence intensity was analyzed.

\subsection{Assay for Mitochondrial Enzyme Activities}

Before analysis, the mitochondrial samples were freeze-thawed and gently shaken three times to ensure mitochondrial reached the maximum activity. The NADH-ubiquinone reductase (Complex I) activity was determined by monitoring the reduction of DCPIP at $600 \mathrm{~nm}$ upon addition of assay buffer $\left(10 \times\right.$ buffer containing $0.5 \mathrm{M}$ Tris- $\mathrm{HCl}, 2 \mathrm{mM} \mathrm{NaN}_{3}, 10 \mu \mathrm{M}$ antimycin A, 1\% BSA, $0.5 \mathrm{mM}$ coenzyme $\mathrm{Q}_{1}, \mathrm{pH}$ 8.1). The reaction was started by adding $200 \mu \mathrm{M} \mathrm{NADH}$ and scanned for $2 \mathrm{~min}$. Rotenone $(3 \mu \mathrm{M})$ was added to the reaction system as blank control [46]. Succinate-ubiquinone reductase (Complex II) was assayed in the assay buffer $(10 \times$ buffer containing $0.5 \mathrm{M}$ phosphate buffer,

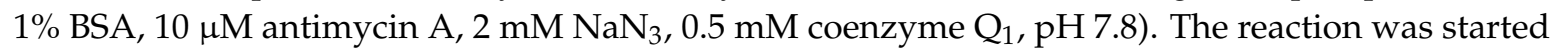
with $10 \mathrm{mM}$ succinate performed as described [47]. Ubiquinol-cytochrome c reductase (Complex III) was assayed by monitoring the reduction rate of cytochrome $\mathrm{c}$ at $550 \mathrm{~nm}$ upon the addition of assay 
buffer (0.5 M Tris-HCl, $2 \mathrm{mM} \mathrm{NaN}_{3}, 0.8 \%$ Tween-20, $1 \%$ BSA, 2 mM decylubiquinol, $\left.\mathrm{pH} 7.8\right)$ with $40 \mu \mathrm{M}$ cytochrome c [38]. Cytochrome c oxidase (Complex IV) was assayed by the rate of oxygen consumption. Assay buffer contained $50 \mathrm{mM}$ phosphate buffer, $\mathrm{pH} 7.0,0.1 \% \mathrm{BSA}, 0.2 \%$ Tween-20 and $30 \mu \mathrm{g} / \mathrm{mL}$ of mitochondrial protein. The non-enzymic rate of oxygen consumption was recorded before starting the reaction by addition of $40 \mu \mathrm{M}$ reduced cytochrome $\mathrm{c}$ and scanned at $550 \mathrm{~nm}$ for $2 \mathrm{~min}$ [48]. All assays were conducted at $30^{\circ} \mathrm{C}$.

\subsection{GC-MS Analysis}

The components of the PSE were identified by GC-MS analysis as described previously [17]. The GC-MS was carried on a Varian Gas Chromatograph series 3800 fitted with a DB-5 capillary column $(30 \mathrm{~m} \times 0.32 \mathrm{~mm}$, film thickness $0.25 \mu \mathrm{m})$ coupled with a 4000 series mass detector under the following conditions: injection volume $0.5 \mu \mathrm{L}$ with split ratio $1: 60$, helium as carrier gas at $1.0 \mathrm{~mL} / \mathrm{min}$ constant flow mode, injector temperature $250{ }^{\circ} \mathrm{C}$, oven temperature was programmed from 50 to $280{ }^{\circ} \mathrm{C}$ at $5{ }^{\circ} \mathrm{C} / \mathrm{min}$. Mass spectra: electron impact (EI+) mode, $70 \mathrm{eV}$ and ion source temperature $250^{\circ} \mathrm{C}$. Mass spectra were recorded over 40-600 a.m.u range.

\subsection{Statistical Analysis}

Each experiment was performed in triplicate, and statistical comparisons of the results were calculated using one-way ANOVA. Analysis of variance for individual parameters was performed based on mean values to determine the significance at $p<0.05$. Data were expressed as means \pm standard deviations.

\section{Conclusions}

In this study, the results have demonstrated that the extract from papaya could induce apoptosis in C. albicans cells significantly. In the apoptotic process, the extract induced intracellular accumulation of ROS followed by the collapse of MMP, then further leaded to the decreasing of the mitochondria Complex I and Complex III activities. Collectively, the results indicated a role of the extract as a novel drug for cardiac diseases which is a rich and high-purity source of BITC.

Author Contributions: Weijun Chen conceived and designed the experiments; Tao Zhang performed the experiments, analyzed the data and wrote the paper.

Conflicts of Interest: The authors declare no conflict of interest.

\section{References}

1. Yon, R.M. Papaya: Fruit Development, Postharvest Physiology, Handling and Marketing in ASEAN; ASEAN Food Handling Bureau: Kuala Lumpur, Malaysia, 1994.

2. Chan, H.; Tang, C.-S. The chemistry and biochemistry of papaya. Trop. Foods 1979, 1, 33-55.

3. Salunkhe, D.K.; Kadam, S. Handbook of Fruit Science and Technology: Production, Composition, Storage, and Processing; CRC Press: Boca Raton, FL, USA, 1995.

4. O'brien, R.D. Fats and Oils: Formulating and Processing for Applications; CRC Press: Boca Raton, FL, USA, 2010.

5. Adebiyi, A.; Ganesan Adaikan, P.; Prasad, R. Tocolytic and toxic activity of papaya seed extract on isolated rat uterus. Life Sci. 2003, 74, 581-592. [CrossRef] [PubMed]

6. Rao, R.; Jamir, N. Ethnobotanical studies in Nagaland. I. Medicinal plants. Econ. Bot. 1982, 36, 176-181.

7. Puangsri, T.; Abdulkarim, S.; Ghazali, H. Properties of Carica papaya L. (papaya) seed oil following extractions using solvent and aqueous enzymatic methods. J. Food Lipids 2005, 12, 62-76. [CrossRef]

8. Blekas, G.; Tsimidou, M.; Boskou, D. Contribution of $\alpha$-tocopherol to olive oil stability. Food Chem. 1995, 52, 289-294. [CrossRef]

9. Malacrida, C.R.; Kimura, M.; Jorge, N. Characterization of a high oleic oil extracted from papaya (Carica papaya L.) seeds. Food Sci. Technol. 2011, 31, 929-934. [CrossRef]

10. Masson Salaué, L.; Camilo, C.; Torija, M.E. Caracterización del aceite de coquito de palma chilena (Jubaea chilensis). Grasas Y Aceites 2008, 59, 33-38. 
11. Emeruwa, A. Antibacterial substance from Carica papaya fruit extract. J. Nat. Prod. 1982, 45, $123-127$. [CrossRef] [PubMed]

12. Chinoy, N.; D'souza, J.; Padman, P. Effects of crude aqueous extract of Carica papaya seeds in male albino mice. Reproduct. Toxicol. 1994, 8, 75-79. [CrossRef]

13. Lohiya, N.; Goyal, R.B. Antifertility investigations on the crude chloroform extract of Carica papaya Linn. seeds in male albino rats. Indian J. Exp. Biol. 1992, 30, 1051-1055. [PubMed]

14. Lohiya, N.; Manivannan, B.; Bhande, S.; Panneerdoss, S.; Garg, S. Perspectives of contraceptive choices for men. Indian J. Exp. Biol. 2005, 43, 1042-1047. [PubMed]

15. Chinoy, N.; Padman, P. Antifertility investigations on the benzene extract of Carica papaya seeds in male albino rats. J. Med. Aromat. Plants Sci. 1996, 18, 489-494.

16. Lohiya, N.K.; Manivannan, B.; Garg, S. Toxicological investigations on the methanol sub-fraction of the seeds of Carica papaya as a male contraceptive in albino rats. Reproduct. Toxicol. 2006, 22, 461-468. [CrossRef] [PubMed]

17. Kermanshai, R.; McCarry, B.E.; Rosenfeld, J.; Summers, P.S.; Weretilnyk, E.A.; Sorger, G.J. Benzyl isothiocyanate is the chief or sole anthelmintic in papaya seed extracts. Phytochemistry 2001, 57, 427-435. [CrossRef]

18. Calderone, R.A.; Clancy, C.J. Candida and Candidiasis; ASM Press: Bel Air, MD, USA, 2012.

19. Achkar, J.M.; Fries, B.C. Candida infections of the genitourinary tract. Clin. Microbiol. Rev. 2010, $23,253-273$. [CrossRef] [PubMed]

20. Gudlaugsson, O.; Gillespie, S.; Lee, K.; Berg, J.V.; Hu, J.; Messer, S.; Herwaldt, L.; Pfaller, M.; Diekema, D. Attributable mortality of nosocomial candidemia, revisited. Clin. Infect. Dis. 2003, 37, 1172-1177. [CrossRef] [PubMed]

21. Çıtak, S.; Özçelik, B.; Cesur, S.; Abbasoglu, U. In vitro susceptibility of Candida species isolated from blood culture to some antifungal agents. Jpn. J. Infect. Dis. 2005, 58, 44-46.

22. Seneviratne, C.J.; Wong, R.W.; Samaranayake, L.P. Potent anti-microbial activity of traditional Chinese medicine herbs against Candida species. Mycoses 2008, 51, 30-34. [CrossRef] [PubMed]

23. He, X.; Ma, Y.; Yi, G.; Wu, J.; Zhou, L.; Guo, H. Chemical composition and antifungal activity of Carica Papaya Linn. seeds essential oil against Candida spp. Lett. Appl. Microbiol. 2017, 64, 350-354. [CrossRef] [PubMed]

24. Singh, O.; Ali, M. Phytochemical and antifungal profiles of the seeds of Carica papaya L. Indian J. Pharm. Sci. 2012, 73, 447-451.

25. Hamza, O.; Matee, M.; Moshi, M.; Simon, E.; Mugusi, F.; Mikx, F.; Helderman, W.; Rijs, A.; van der Ven, A.; Verweij, P. Species distribution and in vitro antifungal susceptibility of oral yeast isolates from Tanzanian HIV-infected patients with primary and recurrent oropharyngeal candidiasis. BMC Microbiol. 2008, 8. [CrossRef] [PubMed]

26. Wu, X.-Z.; Cheng, A.-X.; Sun, L.-M.; Sun, S.-J.; Lou, H.-X. Plagiochin E, an antifungal bis (bibenzyl), exerts its antifungal activity through mitochondrial dysfunction-induced reactive oxygen species accumulation in Candida albicans. Biochim. Biophys. Acta 2009, 1790, 770-777. [CrossRef] [PubMed]

27. Song, F.; Zhang, L.; Yu, H.-X.; Lu, R.-R.; Bao, J.-D.; Tan, C.; Sun, Z. The mechanism underlying proliferation-inhibitory and apoptosis-inducing effects of curcumin on papillary thyroid cancer cells. Food Chem. 2012, 132, 43-50. [CrossRef] [PubMed]

28. Nakamura, Y.; Yoshimoto, M.; Murata, Y.; Shimoishi, Y.; Asai, Y.; Park, E.Y.; Sato, K.; Nakamura, Y. Papaya seed represents a rich source of biologically active isothiocyanate. J. Agric. Food Chem. 2007, 55, 4407-4413. [CrossRef] [PubMed]

29. Li, W.; Du, Y.; Zhang, Y.; Chi, Y.; Shi, Z.; Chen, W.; Ruan, M.; Zhu, H. Optimized formation of benzyl isothiocyanate by endogenous enzyme and its extraction from Carica papaya seed. Trop. J. Pharm. Res. 2014, 13, 1303-1311. [CrossRef]

30. Lee, W.J.; Lee, M.H.; Su, N.W. Characteristics of papaya seed oils obtained by extrusion-expelling processes. J. Sci. Food Agric. 2011, 91, 2348-2354. [CrossRef] [PubMed]

31. Okeniyi, J.A.; Ogunlesi, T.A.; Oyelami, O.A.; Adeyemi, L.A. Effectiveness of dried Carica papaya seeds against human intestinal parasitosis: A pilot study. J. Med. Food 2007, 10, 194-196. [CrossRef] [PubMed] 
32. Martins, M.D.; Lozano-Chiu, M.; Rex, J.H. Point prevalence of oropharyngeal carriage of fluconazole-resistant Candida in human immunodeficiency virus-infected patients. Clin. Infect. Dis. 1997, 25, 843-846. [CrossRef] [PubMed]

33. Tavakkol-Afshari, J.; Brook, A.; Mousavi, S.H. Study of cytotoxic and apoptogenic properties of saffron extract in human cancer cell lines. Food Chem. Toxicol. 2008, 46, 3443-3447. [CrossRef] [PubMed]

34. Kobayashi, D.; Kondo, K.; Uehara, N.; Otokozawa, S.; Tsuji, N.; Yagihashi, A.; Watanabe, N. Endogenous reactive oxygen species is an important mediator of miconazole antifungal effect. Antimicrob. Agents Chemother. 2002, 46, 3113-3117. [CrossRef] [PubMed]

35. Hwang, I.; Lee, J.; Lee, D.G. Indole-3-carbinol generates reactive oxygen species and induces apoptosis. Biol. Pharm. Bull. 2011, 34, 1602-1608. [CrossRef] [PubMed]

36. Laparra, J.M.; Vélez, D.; Barberá, R.; Farré, R.; Montoro, R. $\mathrm{As}_{2} \mathrm{O}_{3}$ induced oxidative stress and cycle progression in a human intestinal epithelial cell line (Caco-2). Toxicology 2008, 22, 444-449. [CrossRef] [PubMed]

37. Vander Heiden, M.G.; Chandel, N.S.; Williamson, E.K.; Schumacker, P.T.; Thompson, C.B. Bcl-xL regulates the membrane potential and volume homeostasis of mitochondria. Cell 1997, 91, 627-637. [CrossRef]

38. Sun, L.; Shen, W.; Liu, Z.; Guan, S.; Liu, J.; Ding, S. Endurance exercise causes mitochondrial and oxidative stress in rat liver: Effects of a combination of mitochondrial targeting nutrients. Life Sci. 2010, 86, 39-44. [CrossRef] [PubMed]

39. Pitkanen, S.; Robinson, B.H. Mitochondrial complex I deficiency leads to increased production of superoxide radicals and induction of superoxide dismutase. J. Clin. Investig. 1996, 98, 345-351. [CrossRef] [PubMed]

40. Xiao, D.; Powolny, A.; Singh, S. Benzyl isothiocyanate targets mitochondrial respiratory chain to trigger reactive oxygen species-dependent apoptosis in human breast cancer cells. J. Biol. Chem. 2008, 283, 30151-30163. [CrossRef] [PubMed]

41. Kasiappan, R.; Jutooru, I.; Karki, K.; Hedrick, E.; Safe, S.H. Benzylisothiocyanate (BITC) induces ROS-dependent repression of STAT3 by downregulation of specificity proteins in pancreatic cancer. J. Biol. Chem. 2016, 291, 27122-27133. [CrossRef] [PubMed]

42. Sahu, R.; Zhang, R.; Srivastava, S. Generation of ROS by benzyl isothiocyanate results in the activation of MAPK leading to induction of apoptosis in human pancreatic cancer cells. Cancer Res. 2008, 68, 2355.

43. Eloff, J. A sensitive and quick microplate method to determine the minimal inhibitory concentration of plant extracts for bacteria. Planta Medica 1998, 64, 711-713. [CrossRef] [PubMed]

44. Niimi, K.; Harding, D.; Parshot, R.; King, A.; Lun, D.; Decottignies, A.; Niimi, M.; Lin, S.; Cannon, R.; Goffeau, A. Chemosensitization of fluconazole resistance in Saccharomyces cerevisiae and pathogenic fungi by a Doctapeptide derivative. Antimicrob. Agents Chemother. 2004, 48, 1256-1271. [CrossRef] [PubMed]

45. Zhao, D.L.; Zou, L.B.; Lin, S.; Shi, J.G.; Zhu, H.B. Anti-apoptotic effect of esculin on dopamine-induced cytotoxicity in the human neuroblastoma SH-SY5Y cell line. Neuropharmacology 2007, 53, 724-732. [CrossRef] [PubMed]

46. Trounce, I.A.; Kim, Y.L.; Jun, A.S.; Wallace, D.C. Assessment of mitochondrial oxidative phosphorylation in patient muscle biopsies, lymphoblasts, and transmitochondrial cell lines. Methods Enzymol. 1996, 264, 484-509. [PubMed]

47. Picklo, M.J.; Amarnath, V.; McIntyre, J.O.; Graham, D.G.; Montine, T.J. 4-Hydroxy-2(E)-nonenal inhibits CNS mitochondrial respiration at multiple sites. J. Neurochem. 1999, 72, 1617-1624. [CrossRef] [PubMed]

48. Humphries, K.M.; Szweda, L.I. Selective inactivation of $\alpha$-ketoglutarate dehydrogenase and pyruvate dehydrogenase: Reaction of lipoic acid with 4-hydroxy-2-nonenal. Biochemistry 1998, 37, 15835-15841. [CrossRef] [PubMed]

(C) 2017 by the authors. Licensee MDPI, Basel, Switzerland. This article is an open access article distributed under the terms and conditions of the Creative Commons Attribution (CC BY) license (http://creativecommons.org/licenses/by/4.0/). 